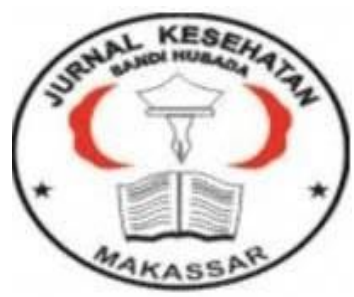

\author{
Jurnal Ilmiah Kesehatan Sandi Husada \\ hhttps://akper-sandikarsa.e-journal.id/JIKSH \\ Volume 9, Nomor 2, Desember 2020, pp 597-603 \\ p-ISSN: 2354-6093 dan e-ISSN: 2654-4563 \\ DOI: $10.35816 /$ jiskh.v10i2.360
}

\title{
Indeks Massa Tubuh dengan Kadar Hb-A1c pada Pasien Diabetes Melitus Tipe II
}

Body Mass Index with Hb-A1c Levels in Type II Diabetes Mellitus Patients

\author{
Irman saputra ${ }^{1}$, Firhat Esfandiari' ${ }^{2}$, Esteria Marhayuni ${ }^{3}$, M Nur ${ }^{4}$ \\ ${ }^{1}$ Program Studi Kedokteran Fakultas Kedokteran Universitas Malahayati \\ 2Fakultas Kedokteran, Universitas Malahayati Lampung \\ ${ }^{34}$ Instalasi Laboratorium Patologi Klinik RSUD Pringsewu Lampung
}

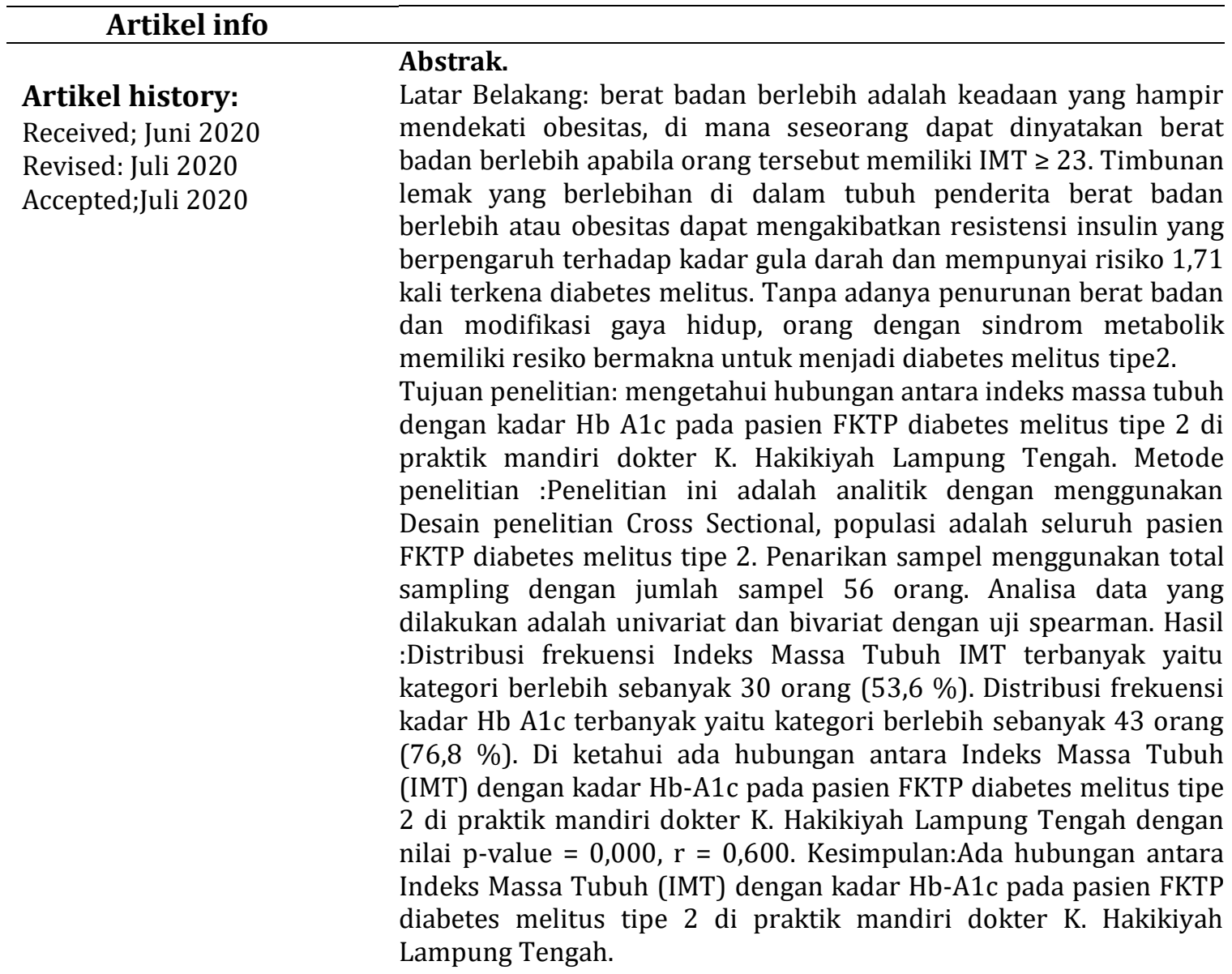


Abstract. Backgrounds:Excess weight is a situation that is almost close to obesity, where a person can be declared overweight if the person has a $B M I \geq 23$. Excessive fat deposits in the body of patients with excess weight or obesity can lead to insulin resistance which affects the patient's blood sugar and have a risk of1,71 times developing levels diabetes melitus. Without weight loss and lifestyle modification, people with metabolic syndrome have a significant risk of becoming type 2 diabetes melitus. Purpose:To find out the relationship between body mass index with $\mathrm{Hb}$-A1c in patients FKTP diabetes melitus type 2 in independent practice doctor $K$. Hakikiyah Central Lampung. Methods:This study is an analytical study and used Cross Sectional Approach, the population in this study is the patients FKTP diabetes melitus type 2 in independent practice doctor K. Hakikiyah Central Lampung. Sampling methods used the total sampling with a total of 56 people. Data analysis was done by univariate and bivariate analysis with spearman test. Results:Result showed that the most BMI Body Mass Index was in overweight category with total of 30 people $(53,6 \%)$. The highest frequency distribution of $\mathrm{Hb}$-A1c levels is the highest category of 40 people $(71,4 \%)$. It was found that there was a relations between Body Mass Index (BMI) with $\mathrm{Hb}-\mathrm{AlC}$ in patients FKTP diabetes mellitus type 2 in independent practice doctor $K$. Hakikiyah Central Lampung, with $p$-value $=0.000, r=$ 0,600 . Conclusion:It is known that there is a relationship between Body Mass Index (BMI) with Hb-A1c in patients FKTP diabetes melitus type 2 in independent practice doctor K. Hakikiyah Central Lampung August 2019. Keyword : body mass index (BMI), Hb-A1c, diabetes melitus tipe 2

Keywords:

Indeks Masa Tubuh;

Kadar $\mathrm{Hb}-\mathrm{A1c}$;

DMT2;
Coresponden author:

Email: irman.malahayati@gmail.com

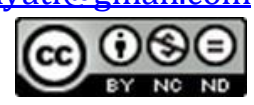

artikel dengan akses terbuka dibawah lisensi BCC BY NC ND-4.0

\section{Pendahuluan}

Diabetes Melitus (DM) merupakan suatu kelompok penyakit metabolik dengan karakteristik hiperglikemia yang terjadi karena kelainan sekresi insulin, kerja insulin atau kedua-duanya. Diabetes millitus ditegakkan bila nilai glukosa darah puasa $>126 \mathrm{mg} / \mathrm{dl}$ dan glukosa darah 2 jam PP >200mg/dl (Depkes RI, 2014). Hiperglikemia kronik pada diabetes berhubungan dengan kerusakan jangka panjang, disfungsi atau kegagalan beberapa organ tubuh, terutama mata, ginjal, saraf, jantung, dan pembuluh darah (Purnamasari, 2014).

Secara global terdapat 382 juta orang yang hidup didunia dengan diabetes pada tahun 2013, dan pada tahun 2035 akan meningkat menjadi 592 juta orang dengan diabetes melitus (IDF, 2014). Prevalensi DM meningkat dari 5,9\% sampai 7,1\% (246-380 jiwa) 
diseluruh dunia pada kelompok usia 20-79 tahun. Proporsi relatif dari DM bervariasi yaitu 1:5 pada populasi di Negara maju dan 1:19 di Negara berkembang (WHO, 2017).

International Diabetes Federation (IDF) menyatakan bahwa lebih dari 371 juta orang di dunia yang berumur 20-79 tahun menderita DM. Indonesia merupakan negara urutan ke7 dengan prevalensi DM tertinggi. IDF memperkirakan pada tahun 2035 jumlah insiden DM akan mengalami peningkatan menjadi 205 juta kasus di antara usia penderita DM 4059 tahun. Indonesia berada di posisi ke 2 terbanyak di kawasan Asia Tenggara dan angka kejadian DM di Indonesia sebesar 9.116 kasus (Perkeni, 2015).

Di Indonesia proporsi penderita DM juga menunjukkan kenaikan. Berdasarkan hasil Riset Kesehatan Dasar (RISKESDAS) tahun 2013 didapatkan bahwa proporsi penderita DM pada usia $\geq 15$ tahun meningkat hampir 2x lipat dibanding pada tahun 2007. Dengan angka proporsi yakni 6,9\% diperkirakan jumlah absolut penderita DM di Indonesia telah mencapai sekitar 12 juta jiwa (Kemenkes RI, 2014). Pravalensi DM pada tahun 2007 Provinsi Lampung mengalami peningkatan dari 0,4\%, menjadi 1,7\% pada tahun 2018 (Riskesdas 2007 dan 2018). Lampung tengah berdasarkan data di Dinas Kesehatan mengalami peningkatan sebesar 9\% yaitu sebanyak 581 kasus (Riskesdas, 2007)

Faktor resiko meningkatnya jumlah penderita DM dapat dikelompokkan oleh faktor resiko yang tidak dimodifikasi diantaranya adalah ras dan etnik, riwayat dengan keluarga DM, umur, riwayat melahirkan bayi dengan BB lahir bayi $>4 \mathrm{~kg}$ dan riwayat lahir dengan berat badan lahir rendah $<2,5 \mathrm{~kg}$ dan faktor yang dapat dimodifikasi berat badan lebih (IMT $\geq 23 \mathrm{~kg} / \mathrm{m}^{2}$ ), kurangnya aktivitas fisik, hipertensi ( $>140 / 90 \mathrm{mmHg}$ ), dislipidemia (HDL $<35 \mathrm{mg} / \mathrm{dl}$ dan atau trigliserida $>250 \mathrm{mg} / \mathrm{dl}$ ) dan diet tidak sehat. Faktor lain yang terkait dengan risiko DM penderita Polycistic Ovary Syndrome (PCOS) atau keadaan klinis lain yang terkait dengan resistensi insulin. Penderita sindrom metabolik yang memiliki riwayat Toleransi Glukosa Terganggu (TGT) atau Glukosa Darah Puasa Terganggu (GDPT) sebelumnya. Penderita yang memiliki riwayat penyakit kardivaskular, seperti stroke, PJK, atau PAD (Perkeni, 2015)

Kadar glukosa darah yang tinggi dan berlangsung lama atau kronis seperti pada penderita DM tipe 2, akan bereaksi dengan gugus $\mathrm{N}$ protein yang disebut dengan glikosilasi protein. Penentuan kadar glikosilasi Hb (HbA1c) merupakan pemantau peninggian kadar glukosa darah rata-rata selama 1-3 bulan sebelumnya (Paputungan, 2014). Obesitas merupakan salah satu faktor yang mempengaruhi timbulnya penyakit DM tipe 2. Salah satu cara mengetahui adanya obesitas adalah dengan menilai Indeks Massa Tubuh (IMT).Peningkatan IMT menyebabkan meningkatnya timbunan lemak bebas yang tinggi yang akhirnya dapat memicu oksidasi lemak yang menghambat penggunaan glukosa dalam otot (Purwandari, 2014). IMT merupakan pengukuran yang membandingkan berat dan tinggi badan. Secara klinis IMT yang bernilai $\geq 23,0 \mathrm{~kg} / \mathrm{m} 2$ disebut overweight dan nilai IMT 25,0 - 29,9 kg/m2 di sebut obesitas. Berat badan berlebih menjadi salah satu resiko penyebab kematian di dunia (Guyton, 2014). Sekitar 70\% penderita diabetes adalah over weight dan lebih dari 50\% pasien dengan obesitas mengalami penurunan toleransi glukosa (Syahbudin, 2013).

Hasil penelitian ini sejalan dengan yang dilakukan oleh Look AHEAD Research Group pada tahun 2007, 4 pasien diabetes yang diintervensi gaya hidupnya sehingga mengalami penurunan berat badan akan mengalami peningkatan kontrol glikemik dan pengurangan kadar Hb-A1c. Dari hasil penelitian yang dilakukan oleh Bella Bonita di RSUP DR. Mohammad Hoesin Palembang pada tahun 2017, dari 21 pasien dengan kategori IMT resiko tinggi , 2 (9,5\%) pasien memiliki kadar Hb-A1c normal dan 19 (90,5\%) pasien memiliki kadar Hb-A1c tinggi. 
Berdasarkan uraian diatas peneliti tertarik melakukan penelitian mengenai Hubungan Antara Indeks Masa Tubuh dengan kadar Hb-A1c Pasien Diabetes Melitus Tipe II di Praktik Mandiri Dokter K. Kikiyah Lampung Tengah Agustus 2019

\section{Metode}

Penelitian ini adalah analitik dengan menggunakan Desain penelitian Cross Sectional, populasi adalah seluruh pasien FKTP diabetes melitus tipe 2 di praktik mandiri dokter K. Hakikiyah Lampung Tengah. Penarikan sampel menggunakan total sampling dengan jumlah sampel 56 orang. Analisa data yang dilakukan adalah univariat dan bivariat dengan uji spearman.

\section{Hasil Dan Pembahasan}

Tabel 1. Distribusi frekuensi Indeks Massa Tubuh

\begin{tabular}{lcc}
\hline \multicolumn{1}{c}{ Indeks Massa Tubuh (IMT) } & Jumlah & Persentase \\
\hline Normal & 26 & $46,4 \%$ \\
Berlebih & 30 & $53,6 \%$ \\
\hline Total & $\mathbf{5 6}$ & $\mathbf{1 0 0}$ \\
\hline Kadar Kolesterol total & & $28,6 \%$ \\
\hline Prediabetes & 16 & $71,4 \%$ \\
\hline Diabetes melitus & 40 & $\mathbf{1 0 0}$ \\
\hline Total & $\mathbf{5 6}$ & P-Value \\
\hline Variabel & $\mathrm{R}$ & 0,000 \\
\hline IMT dengan kadar Hb-A1c & 0,600 & \\
\hline
\end{tabular}

Berdasarkan hasil penelitian diketahui bahwa dari 56 responden yang diteliti,terlihat bahwa yang terbanyak dengan IMT kategori berlebih sebanyak 30 orang $(53,6 \%)$ selebihnya didapatkan IMT kategori normal yaitu 26 orang $(46,4 \%)$.

IMT merupakan alat atau cara yang sederhana untuk memantau status gizi orang dewasa khususnya yang berkaitan dengan kekurangan dan kelebihan berat badan. Berat badan yang kurang dapat meningkatkan risiko terhadap penyakit infeksi, sedangkan berat badan berlebih akan meningkatkan resiko terkena penyakit degeneratif, sehingga mempertahankan berat badan normal memungkinkan seseorang dapat mencapai usia harapan hidup yang lebih panjang (Supariasa dkk, 2012).

Hasil IMT yang masuk kategori berat badan berlebih perlu diwaspadai. Berat badan berlebih merupakan faktor resiko yang berperan penting terhadap penyakit diabetes melitus. Orang dengan berat badan berlebih memiliki masukan kalori yang berlebih. Sel beta kelenjar pankreas akan mengalami kelelahan dan tidak mampu untuk memproduksi insulin yang cukup untuk mengimbangi kelebihan masukan kalori. Akibatnya kadar glukosa darah akan tinggi yang akhirnya akan menjadi DM (Sugiritama, 2015). 
Menurut peneliti timbunan lemak yang berlebihan di dalam tubuh penderita obesitas dapat mengakibatkan resistensi insulin yang berpengaruh terhadap kadar gula darah yang menyebabkan terjadinya diabetes melitus. Kelebihan berat badan baik tingkat ringan maupun sedang, karena kelebihan berat badan meningkatkan resiko penyakit degeneratif, dimana diabetes melitus merupakan salah satu penyakit degenerative.

Berdasarkan hasil penelitian diketahui bahwa dari 56 responden yang diteliti, terlihat terlihat bahwa yang terbanyak dengan kadar Hb-A1c kategori berlebih sebanyak 40 orang $(71,4 \%)$, selebihnya didapatkan kadar Hb-A1c kategori normal yaitu 16 orang $(28,6 \%)$. Diabetes Melitus (DM) merupakan suatu kelompok penyakit metabolic dengan karakteristik hiperglikemia yang terjadi karena kelainan sekresi insulin, kerja insulin atau kedua-duanya. Secara global terdapat 382 juta orang yang hidup didunia dengan diabetes pada tahun 2013, dan pada tahun 2035 akan meningkat menjadi 592 juta orang dengan diabetes mellitus. Dua kelainan fisiologis utama pada prediabetes adalah resistensi insulin dan disfungsi sel beta pankreas, dan perubahan ini terwujud sebelum terjadinya kelainan kadar glukosa (WHO, 2017).

Menurut peneliti upaya agar kadar Hb-A1c tetap normal salah satunya dengan pencapaian status gizi yang baik yaitu diet, latihan, pemantauan, terapi (jika diperlukan), dan pendidikan. Penanganan di sepanjang perjalanan penyakit diabetes melitus akan bervariasi mengikuti kemajuan dalam metode terapi yang dihasilkan dari riset, perubahan pada gaya hidup, keadaan fisik, dan mental dari penderita diabetes melitus sendiri. Sehingga diharapkan dapat mengontrol kadar Hb-A1c secara rutin agar dapat dilakukan tindakan pencegahan sedini mungkin.

Berdasarkan hasil analisis dapat dilihat bahwa $r=0,600$ dengan $p$-value 0,000 yang berarti hubungan antara Indeks Massa Tubuh (IMT) dengan kadar Hb-A1c memiliki korelasi yang positif yang kuat dengan hubungan yang signifikan. Hal ini berarti, artinya apabila tingkat Indeks Massa Tubuh (IMT) tinggi maka kadar Hb-A1c juga akan tinggi begitupula sebaliknya, apabila Indeks Massa Tubuh (IMT) rendah maka kadar Hb-A1c juga akan rendah. Hasil penelitian ini sejalan dengan yang dilakukan oleh Look AHEAD Research Group pada tahun 2007, 4 pasien diabetes yang diintervensi gaya hidupnya sehingga mengalami penurunan berat badan akan mengalami peningkatan kontrol glikemik dan pengurangan kadar Hb-A1c. Dari hasil penelitian yang dilakukan oleh Bella Bonita di RSUP DR. Mohammad Hoesin Palembang pada tahun 2017, dari 21 pasien dengan kategori IMT resiko tinggi , 2 (9,5\%) pasien memiliki kadar Hb-A1c normal dan 19 $(90,5 \%)$ pasien memiliki kadar Hb-A1c tinggi.

Overweight dan obesitas yang keduanya didefinisikan sebagai kelebihan berat badan, secara umum merupakan keadaan kegemukan dengan perbedaan tingkatan yaitu kelebihan berat badan tingkat ringan (overweight) dan tingkat berat (obesitas) yang dibedakan sesuai dengan kriteria kegemukan berdasarkan pengukuran indeks massa tubuh (IMT) atau disebut juga body mass index(BMI). Overweight adalah keadaan yang hampir mendekati obesitas, seseorang dapat dinyatakan overweight apabila orang tersebut memiliki IMT $\geq 23$. Selain itu, kondisi overweight juga lazim disebut dengan kondisi pre-obese (WHO, 2010). Diabetes melitus terjadi pada orang yang memiliki status gizi gemuk atau tidak gemuk. Namun sebagian besar DMT2 terjadi pada orang obesitas/ overweight. Hubungan antara obesitas dengan DMT2 telah diketahui sejak beberapa dekade sebelumnya, dimana obesitas viseral sering ditemukan pada sebagian besar pasien. Resistensi insulin ditemukan bahkan pada obesitas sederhana yang tidak diikuti oleh hiperglikemia, menunjukan suatu abnormalitas yang mendasar pada pengisyaratan insulin dalam keadaan kelebihan lemak. Istilah sindrom metabolik telah dipakai untuk sekelompok temuan yang didominasi oleh obesitas viseral, diikuti oleh resistensi insulin, 
intoleransi glukosa, dan faktor resiko seperti tekanan darah tinggi dan profil lemak yang abnormal (Perkeni, 2015).

Hasil penelitian ini berbeda dengan penelitian yang dilakukan Nurul (2015) yang menunjukkan bahwa hampir setengah dari responden mempunyai IMT kelebihan berat badan tingkat ringan dan sebagian besar responden mempunyai kadar gula darah tergolong lebih dari rata-rata dengan menggunakan hasil Uji Pearson $p$ value 0,895 berarti tidak ada hubungan IMT dengan kadar gula darah pada penderita diabetes melitus di Desa Barengkrajan Kecamatan Krian Kabupaten Sidoarjo. Hasil penelitian ini menyebutkan bahwa penderita diabetes sehingga kadar gula darahnya cenderung sudah tinggi atau mengalami intoleransi, sehingga IMT tidak mempengaruhi tinggi rendahnya kadar gula darah penderita diabetes melitus. (Nurul, 2015). Faktor resiko meningkatnya jumlah penderita DM dapat dikelompokkan oleh faktor resiko yang tidak dimodifikasi diantaranya adalah ras dan etnik, umur, jenis kelamin, riwayat keluarga dengan DM, riwayat melahirkan bayi dengan $\mathrm{BB}>4000 \mathrm{gr}$ dan riwayat lahir dengan berat badan lahir rendah < 2500 gr. Sedangkan faktor resiko yang dapat dimodifikasi berhubungan dengan perilaku hidup yang kurang sehat, yaitu berat badan lebih, obesitas abdominal/ sentral, kurangnya aktivitas fisik, hipertensi, dislipidemia, diet tidak sehat/ tidak seimbang, riwayat TGT / GDPT dan merokok (Kemenkes RI, 2013).

Timbunan lemak yang berlebihan di dalam tubuh penderita obesitas dapat mengakibatkan resistensi insulin yang berpengaruh terhadap kadar gula darah penderita diabetes melitus. IMT lebih dari sama dengan $25 \mathrm{~kg} / \mathrm{m} 2$ pada orang dewasa dengan obesitas menyebabkan reseptor insulin pada target sel di seluruh tubuh kurang sensitif dan jumlahnya berkurang sehingga insulin dalam darah tidak dapat dimanfaatkan yang berdampak pada penurunan penyerapan gula darah pada jaringan sehingga kadar gula darah meningkat (Ilyas dalam Soegondo, 2007). Tanpa adanya penurunan berat badan dan modifikasi gaya hidup, orang dengan sindrom metabolik memiliki resiko bermakna untuk menjadi DMT2 bermakna, menekankan pentingnya obesitas pada penyakit ini. Resiko diabetes meningkat seiring dengan peningkatan indeks massa tubuh (suatu pengukuran kandungan lemak tubuh) mengasumsikan adanya hubungan yang terkait dosis antara lemak tubuh dan resistensi insulin (Kumar, 2015). Menurut peneliti hasil penelitian ini menunjukkan bahwa IMT berlebih mempengaruhi terjadi nya diabetes, maka untuk mencegah dan mengendalikan penyakit ini masyarakat di Praktik Mandiri Dokter K. Hakikiyah sudah di lengkapi sarana kesehatan yang cukup lengkap, kesadaran masyarakat untuk memeriksakan kesehatan sudah baik khususnya mengecek pemeriksaan labolatorium di dukung dengan keadaan pengecekan labolatorium setiap 3 bulan sekali.

\section{Simpulan Dan Saran}

Hasil penelitian di peroleh dari 56 responden berdasarkan umur terbanyak yakni kategori beresiko ( $\geq 45$ th) sebanyak 49 responden $(87,5 \%)$, jenis kelamin terbanyak yakni pada jenis kelamin perempuan berjumlah 32 responden $(57,1 \%)$, kadar kolesterol total terbanyak yaitu kategori berlebih sebanyak 40 orang $(71,4 \%)$, IMT terbanyak yaitu kategori berlebih sebanyak 30 orang $(53,6 \%)$. Terdapat hubungan indeks massa tubuh (IMT) dengan kadar Hb-A1c dengan nilai $p$-value $=0,000, r=0,600$.

Bagi instansi pencegahan ditujukan untuk masyarakat yang termasuk risiko tinggi yaitu melakukan skrining pemeriksaan laboratorium kadar gula darah terutama dengan berat badan yang obesitas karena menyebabkan reseptor insulin pada target sel di seluruh tubuh kurang sensitif. Sehingga dibutuhkan pola hidup yang sehat seperti pola makan, aktivitas fisik yang rutin, sehingga kadar glukosa darah terpantau baik. 


\section{Daftar Rujukan}

Arora, M., Koley,S., Gupta,S., and Sandhu,J.S., 2007, A Study on Lipid Profile and Body Fat in Patients with Diabetes Melitus, Anthropologist, 9 (4), 295-298

American Diabetes Association.(2018). 2. Classification and diagnosis of diabetes: standards of medical care in diabetes-2018. Diabetes care, 41(Supplement 1), S13-S27.

Erwinanto, E., Putranto, J. N., Tedjasukmana, P., Suryawan, R., Rifqi, S., \& Kasiman, S. (2013). Pedoman Tatalaksana Dislipidemia PERKI 2013. Indonesian Journal of Cardiology, 245-70.

Guyton, AC. (2006). Buku Ajar Fisiologi Kedokteran.Edisi 11. Jakarta: EGC Medical Publisher

Guyton.2014. Buku Ajar Fisologi Kedokteran. Singapore. Penerbit elsevier

Ilyas, E.I. 2007.Manfaat Latihan Jasmani bagi Penyandang Diabetes, dalam Soegondo, S., et al, Penatalaksanaan Diabetes Melitus Terpadu, Jakarta: FKUI.

Kementrian Kesehatan, R. I. (2011). Pedoman Praktis Memantau Gizi Orang Dewasa Kumar dkk.2015. Buku Ajar Patologi Robbins. Edisi 9. Singapore: Penerbit Hooi Ping Che.; hal : 728-731.

Listiyana, A. D., Mardiana, M., \& Prameswari, G. N. (2013). Obesitas sentral dan kadar kolesterol darah total. Jurnal Kesehatan Masyarakat, 9(1), 37-43.

MIMS.2016. Petunjuk Konsultasi, Edisi 15, 2015/2016. Jakarta: Penerbit PT Bhuana Ilmu Populer; Hal : 70-71.

Nainggolan, O., Kristanto, A. Y., \& Edison, H. (2013). Determinan Diabetes Melitus Analisis Baseline Data Studi Kohort Penyakit Tidak Menular Bogor 2011 (the Determinan of Diabetes Melitus (Baseline Data Analysis of Kohort Studies of NonCommunicable Diseases Bogor 2011)). Buletin Penelitian Sistem Kesehatan, 16(3).

Perkeni.2015. Konsensus Pengelolaan dan Pencegahan Diabetes Melitus Tipe 2 di Indonesia.Perkumpulan Endokrinologi Indonesia: PB Perkeni.

Purnamasari, D. 2014. Diagnosis dan Klasifikasi Diabetes Melitus. In Setiati dkk (ed). Buku Ajar Ilmu Penyakit Dalam Jilid II Edisi VI. Jakarta: FKUI, pp: 2323-7.

Price SA, Wilson LM.2006. Patofisiologi konsep klinis proses penyakit. Edisi ke-enam. Jakarta: EGC; hal: 1261-1263.

Suyono, S., 2009. Diabetes Melitus di Indonesia : Buku Ajar Ilmu Penyakit Dalam Jilid III Edisi V. Jakarta. Balai Penerbit Fakultas Kedokteran Universitas Indonesia, Jakarta. $1134 \mathrm{hlm}$.

WHO .(2010).Childhood Overweight and Obesity. Web site: http://www.who.int/dietphysicalactivity/childhood/en/

WHO .(2017). Prevalensi Kejadian Diabetes Melitus.website :who.int/mediacentre/ factsheets/fs312/en/ 